\title{
MANAJEMEN KUALITAS PENDIDIKAN DI MADRASAH IBTIDAIYAH AL-HUSNA CILEDUG KOTA TANGERANG TAHUN 2021
}

\author{
Mastiaroh \\ e-mail:sitimastiaroh69@gmail.com \\ Kepala Madrasah Ibtidaiyah Al-Husna Ciledug Kota Tangerang \\ Imam Mashud \\ imam.mashud21@gmail.com \\ Guru Pendidikan Agama Islam SD Islam YAKMI Kota Tangerang
}

\begin{abstract}
Management is a staple component that cannot be separated from Islamic educational institutions. Without management, the purpose of the institution cannot be realized optimally, effectively, and efficiently. Problems in educational institutions, usually dealing with the service to the customers of Islamic education. This research is a qualitative research aimed at knowing about the planning, organizing, implementation and evaluation of the quality management of Islamic education services in Madrasah Ibtidaiyah Al-Husna Ciledug Tangerang City. The results of this research show that the management planning of quality Islamic education services is conducted with a) to make the Madrasah Work Plan (MWP) which refers to the vision, mission, and the goal of Madrasah Ibtidaiyah Al-Husna Ciledug, b) Determine the needs of the customers of Islamic education through the increase of the Madrasah resources, c) Develop Islamic education programs according to customers ' expectations through the development of Islamic education programs that are poured in the curriculum of the Ibtidaiyah Al-Husna Ciledug. Organizing is done by implementing the quality standards of education and educationally through a) systematic, structured and directional activities, $b$ ) implementing harmonious and mutually co-operation, c) Division of tasks tailored to expertise. Implementation is done by placing personnel who are qualified especially in the activities of public relation that create programs such as relationship marketing, superior customer service, and monitoring the satisfaction of the Guardian students as an Islamic education customer in the Madrasah Ibtidaiyah Al-Husna Ciledug. Internal evaluation conducted in the monthly meeting and external evaluation of the input from the guardian of students who become education customers will be useful to improve the quality of education in the Madrasah Ibtidaiyah Al-Husna Ciledug Kota Tangerang.
\end{abstract}

Keyword: Management, Quality, and Madrasah Education

\section{ABSTRAK}

Manajemen merupakan komponen pokok yang tidak dapat dipisahkan dari lembaga pendidikan Islam. Tanpa manajemen, tujuan lembaga pendidikan tidak dapat diwujudkan secara optimal, efektif, dan efisien. Masalah dalam lembaga pendidikan, biasanya berhadapan dengan layanan terhadap pelanggan pendidikan Islam. Penelitian ini adalah penelitian kualitatif yang bertujuan untuk mengetahui tentang perencanaan, pengorganisasian, pelaksanaan dan evaluasi pada manajemen kualitas pendidikan di Madarasah Ibtidaiyah Al-Husna Ciledug Kota Tangerang. Hasil dari penelitian ini 
menunjukkan bahwa perencanaan manajemen kualitas pendidikan dilakukan dengan a) membuat Rencana Kerja Madrasah (RKM) yang mengacu pada visi, misi, dan tujuan madrasah ibtidaiyah Al-Husna Ciledug, b) menentukan kebutuhan pelanggan pendidikan Islam melalui peningkatan sumber daya madrasah, c) mengembangkan program pendidikan Islam sesuai harapan pelanggan melalui pengembangan program pendidikan Islam yang dituangkan dalam kurikulum madrasah ibtidaiyah Al-Husna Ciledug. Pengorganisasian dilakukan dengan menerapkan standar kualitas pendidikan dan tenaga kependidikan melalui a) kegiatan sistematis, terstruktur dan terarah, b) menerapkan hubungan yang harmonis dan saling bekerjasama, c) pembagian tugas disesuaikan dengan keahlian. Pelaksanaan di lakukan dengan menempatkan tenaga yang qualified terutama dalam kegiatan kehumasan yang membuat program seperti relationship marketing, superior customer service, dan pemantauan kepuasan wali murid sebagai pelanggan pendidikan Islam di madrasah ibtidaiyah Al-Husna Ciledug. Evaluasi dilakukan secara internal yang dilaksanakan pada rapat bulanan dan eksternal berupa masukan dari wali murid yang menjadi pelanggan pendidikan akan berguna untuk meningkatkan kualitas pendidikan di madrasah ibtidaiyah Al-Husna Ciledug Kota Tangerang.

Kata Kunci: Manajemen, Kualitas, dan Pendidikan Madrasah

\section{A. Pendahuluan}

Pada kehidupan keluarga, organisasi, sosial, serta negara, manajemen adalah usaha pertama agar tujuan bisa dicapai secara bersama-sama. Pendidikan merupakan elemen penting pada kehidupan manusia, harus menjadi perhatian yang signifikan dalam hal manajemen. Suatu tolak ukur pendidikan yang baik bagi suatu bangsa atau negara tidak terkecuali bagi kemajuan Islam. ${ }^{1}$ Dalam Islam, pendidikan harus dikelola dan di laksanakan dengan semaksimal mungkin. Manajemen pendidikan Islam adalah sarana untuk meningkatkan kualitas hidup manusia yang dalam situasi terbelakang, secara moral, materi, dan spiritual. ${ }^{2}$.

Di dunia pendidikan, kualitas dapat dilihat sebagai alat yang efektif dalam memperjuangkan eksistensi lembaga pendidikan. ${ }^{3}$ Pada dasarnya, kualitas dapat

\footnotetext{
${ }^{1}$ Sudjana,H.D, Manajemen Program Pendidikan, (Bandung: Falah Production, 2004), h. 2 .

${ }^{2}$ Sulistyorini, Manajemen Pendidikan Islam, (Diktat: STAIN Tulungagung, 2005), h. 4.

${ }^{3}$ Qori kartika, Dinamika Lembaga Pendidikan Mmepertahankan Eksistensi Pada era
}

membantu dalam memenangkan persaingan lembaga pendidikan yang semakin menjamur. Tetapi dengan kualitas yang sama, tidak lagi menjadi jaminan utama dalam berkompetisi. ${ }^{4}$ Untuk dapat memenangkan kompetisi tersebut, lembaga pendidikan harus melihat dimensi kualitas layanan pendidikan dengan baik. Meningkatnya kompetisi antar institusi pendidikan, lembaga pendidikan di tuntut agar dapat mengelaborasi serta menerapkan desain agar mampu memprediksi tren terkini untuk mendapatkan dan menjaga kedudukan kompetisi atau kualitas kompetitif mereka. ${ }^{5}$ Penentuan rencana adalah ketetapan untuk menyelaraskan situasi luar domain yang

kompetitif, Journal of Islamic Educational Management: UIN Raden Fattah, Vol.3, No. 1 Tahun 2017, h. 112.

${ }^{4}$ Addri Eferi, Dinamika Persaingan Antar Lembaga Pendidikan, Journal of Emperical Islamic Education: Stain Kudus, Vol. 2 No. Tahun 2014 h. 99.

${ }^{5}$ Bashori, Strategi Kompetitif Lembaga Pendidikan, Journal Pendidikan Islam (Tadris): IAIN Madura, Volume 12, No. 2 Tahun 2017, h. 162. 
ada di seputar lembaga dan sumber daya pendidikan, serta harapan dan tujuan yang harus dicapai oleh lembaga pendidikan di masa depan. Firman Allah dalam surat AlBaqarah ayat 148

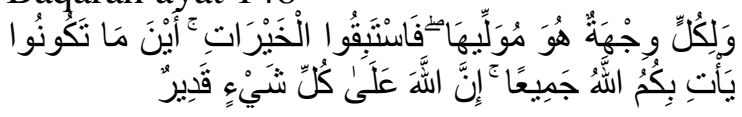

Dan bagi tiap-tiap umat ada kiblatnya (sendiri) yang ia menghadap kepadanya. Maka berlomba-lombalah (dalam membuat) kebaikan. Di mana saja kamu berada pasti Allah akan mengumpulkan kamu sekalian (pada hari kiamat). Sesungguhnya Allah Maha Kuasa atas segala sesuatu (Q.S.2: 148). ${ }^{6}$

Ayat tersebut di atas dapat diartikan secara luas sebagai penyemangat umat Islam untuk selalu bersaing dalam kebaikan. Tentunya, untuk menentukan baik atau tidaknya suatu perbuatan harus sesuai dengan kaidah Allah SWT yaitu AlQur'an dan Hadits. Ayat tersebut di atas jika terkait dalam konteks persaingan bisnis, dikembangkan prinsip persaingan bisnis yang sehat dan akurat. Prinsip persaingan yang sehat dan akurat menurut Islam adalah memberikan layanan terbaik buat konsumen dan tidak melakukan penipuan. $^{7}$

Fungsi manajerial dilakukan oleh semua manajer institusi pendidikan dengan cara yang berdaya guna serta efektif, dan khususnya manajer atau pimpinan sekolah adalah orang yang paling bertanggung jawab untuk mengelola sumber daya lembaga pendidikan. Pendidikan yang berkualitas merupakan ukuran untuk mencocokkan bentuk terhadap dimensi yang dikira esensial oleh konsumen

${ }^{6}$ Departemen Agama RI, Mushaf AlQur'an, (Jakarta: CV Pustaka Al-Kautsar, 2010), h. 17.

${ }^{7}$ Muslich, Etika Bisnis Islami: Landasan Filososfis, Normatif, dan Substnsi Implementatif, (Yogyakarta: Ekonosia, 2004), h. 108. pendidikan. $^{8} \quad$ Penyelenggara lembaga pendidikan harus mengetahui atribut kualitas, sehingga dalam kegiatan operasional dapat merujuk pada kepentingan kualitas pelayanan untuk konsumen. Adapun kegiatan pendidikan di sekolah merupakan sutu bentuk pelayanan (service) yang memiliki bentuk proses yang saling berhubungan.

Salah satu masalah dunia pendidikan adalah rendahnya kualitas pendidikan. Banyak faktor yang menentukan rendahnya mutu pendidikan, salah satunya adalah proses pemberian layanan pendidikan yang masih jauh dari harapan. Penyediaan layanan pendidikan di satu sisi belum menemukan cara yang paling tepat, di sisi lain perkembangan ilmu pengetahuan dan teknologi serta meningkatnya tuntutan akan kebutuhan hidup sosial masyarakat yang telah menjadi pelanggan pendidikan.

Berdasarkan data dan informasi yang diperoleh peneliti bahwa Madrasah Ibtidaiyah Al-Husna Ciledug Kota Tangerang selalu mengupayakan pemaksimalan pelayan pendidikan, salah satunya dengan mengadakan peningkatan pelayanan dari kelas ekonomi menuju kelas bisnis. Kelas bisnis pada Madrasah Ibtidaiyah Al-Husna Ciledug Kota Tangerang bukanlah mengacu atas konsep bisnis semata, melainkan dengan meningkatkan pelayanan dari kegiatan belajar setengah hari menjadi fullday, kelas full Ac, pemanfaatan teknologi informasi pada setiap kelas, pengadaan katering sehat, kegiatan ekstrakurikuler yang cocok dengan minat siswa. Pada kegiatan belajar mengajar, ditemukan aktivitas pendukung yang dikondisikan dari bakat dan minat

\footnotetext{
${ }^{8}$ Maryadi, Manajemen Pemasaran Perguruan Tinggi Sebagai Salah Satu Kunci Keberhasilan Dalam Menghadapi Persaingan, Jurnal Karimah:STIE AMKOP Makassar, Vol. 2 No. 2 Tahun 2017, h. 327.
} 
yang terdapat di Madrasah Ibtidaiyyah AlHusna Ciledug Kota Tangerang seperti penelitian sederhana, bedah sains, field trip, langganan media masa, English day, Arabic day, serta kegiatan extrakurikuler yang bervariatif.

Berlandaskan pemaparan tersebut di atas, membuat penulis tertarik untuk menulis dalam jurnal yang berjudul "Manajemen Kualitas Pendidikan Islam di Madrasah Ibtidaiyah Al-Husna Ciledug Kota Tangerang Tahun 2021".

\section{B. Kajian Teoritik}

Manajemen adalah daya utama pada isntitusi untuk melaksanakan dan mengatur sumber daya manusia dan jasmani. Manajemen adalah faktor penting dalam mencapai suatu tujuan dan kesuksesan pada institusi manapun. George .R Tery dalam bukunya $M$. Manulang menyatakan bahwa manajemen merupakan proses membangun program kegiatan agar tersusun tujuan yang sudah ditetapkan (planning), memastikan orang-orang yang melaksanakan (Organizing), membenahi tim yang terpilih untuk bersama-sama memperlihatkan anjuran serta bimbingan agar berjuang dalam memperoleh tujuan (actuating), memantau jalur implementasi pekerjaan yang dilaksanakan oleh staf serta menakar efektivitas upaya tersebut (Controlling). ${ }^{9}$

James F. Stoner menyatakan bahwa manajemen merupakan metode perencanaan, pengorganisasian, serta penggunaan sumber daya institusi agar tercapai tujuan yang sudah dipastikan. ${ }^{10}$ Robert Kritiner menyatakan bahwa manajemen merupakan cara aktivitas melewati orang lain agar tercapai tujuan

\footnotetext{
${ }^{9}$ M. Manulang, Dasar-Dasar Manajemen, (Yogyakarta: Gajah Mada Univ. Press, 2005), h. 5.

10 James. F. Stoner, Management Sixt Edition, (New Jersey: Prentice Hall, 2005), h.7.
}

pada lingkungan yang telah berganti. ${ }^{11}$ Haroold Koontz dan Heinz Weihrich menyatakan bahwa manajemen merupakan proses rancang serta menentukan lingkungan di mana seseorang dapat bekerja sama dalam satu kelompok yang menginginkan efisiensi sebagai tujuan yang harus dilakukan. ${ }^{12}$ Menurut Lawrence A. Appley dalam bukunya Arun Kumar dan Sachana Sharma menyatakan bahwa Manajemen merupakan talenta pencapaian tujuan yang dilaksanakan melewati upaya orang lain. ${ }^{13}$ Adapun Menurut Mary Parker Follet menyatakan bahwa "Manajemen adalah bakat, karena untuk melaksanakan pekerjaan melalui orang lain ini, membutuhkan keahlian khusus". ${ }^{14}$

Dari pengertian para ilmuwan tersebut maka dapat dilakukan kesimpulan yaitu manajemen merupakan ilmu dan ketrampilan untuk mengatur proses pendayagunaan sumber daya manusia dan sumber lainnya secara maksimal dan praktis agar tercapai tujuan yang telah ditetapkan. Manajemen sebagai ilmu dapat dipahami dan dipelajari, serta menjadi salah satu cabang ilmu pengetahuan, dapat digunakan untuk memecahkan persoalan pada lembaga pendidikan maupun bisnis serta untuk mengambil keputusan oleh seorang pemimpin maupun manajer. Sedangkan manajemen sebagai suatu seni dapat diartikan agar tercapai haluan yang sudah ditentukan, seorang pemimpin sangat terpengaruh pada keahlian yang

${ }^{11}$ Robert Kritiner, Management, 4 Edition, (Boston: Houhgton Miffin Commpany, 1989), h. 9.

${ }^{12}$ Horoold Koontz dan Heinz Weihrich, Essential Of Management an International Perspective, (New Delhi: Tata McGraww-Hill Publishing Company Limited, 2008), h. 6.

13 Arun Kumar dan Rachana Sharma, Principlies Of Busines Management, (New Delhi: Atlantics Publisher anad Distributors, 2000), h. 5.

${ }^{14}$ Novi Erlita, The Website Management of www ppid.dpr.go.id in public information services 2014, American Journal of Humanites and Social Science Reseach, 2018, Vol. II Issue-11, h. 20. 
dimiliki agar dapat mempengaruhi orang lain yang menjadi tanggungjawabnya.

Masalah yang dihadapi lembaga pendidikan Islam sangat beragam, Mulai dari masalah manajemen, kepemimpinan, sumber daya manusia, keuangan, hingga masalah kelembagaan. ${ }^{15}$ Meningkatkan mutu lembaga pendidikan Islam memerlukan teori analisis mutu dan penerapannya dalam setiap proses manajemen. Aspek mutu akan menguntungkan masyarakat pendidikan, hal tersebut dikarenakan peningkatan mutu merupakan tanggung jawab lembaga pendidikan untuk memberikan pelayanan kepada peserta didik. Selain itu, untuk menjamin kualitas lulusannya dapat diterima oleh masyarakat dan dunia kerja.

Deming berpendapat bahwa rendahnya kualitas pendidikan karena disebabkan oleh kegagalan untuk memenuhi beberapa syarat, seperti desain kurikulum yang lemah, bangunan yang tidak memadai, lingkungan kerja yang buruk, sistem dan prosedur yang tidak tepat, jadwal kerja yang tidak teratur, dan kurangnya sumber daya, pengembangan staf yang tidak memadai karena sumber daya yang kurang, motivasi yang minim serta kurangnya daya, kegagalan komunikasi atau masalah peralatan. ${ }^{16}$ Secara umum mutu pendidikan mengacu pada proses pembelajaran dan hasil belajar (learning outcome). Saat ini, lembaga pendidikan Islam perlu membuktikan keberadaannya. Jika tolak ukur mutu menyangkut proses pendidikan, maka lembaga pendidikan Islam dituntut untuk meningkatkan mutu pendidikan. Kemudian, fokus pada kebutuhan stakeholder terkait dengan kompetensi

${ }^{15}$ A.S Nafis, Manajemen Pendidikan Islam. (Yogyakarta: Laksbang Pressindo, 2012), h.11-12

${ }^{16}$ E. Sallis, Total Quality in Education, (London, Kogan Page Limited, 2016), h. 103. lulusan dan kemampuan teknis yang diharapkan pada lingkungan kerja. Menurut Suti. M komponen mutu pendidikan meliputi kesiapan siswa, kemampuan guru, kurikulum, sarana dan prasarana serta partisipasi masyarakat. ${ }^{17}$

Keterkaitan antara permintaan dan keluaran lembaga pendidikan akan berdampak pada peningkatan daya serap lulusan pendidikan Islam di masyarakat. Selain itu, jika indikator kualitas untuk hasil belajar, kualitas lulusan dan prestasi akademik, maka lembaga pendidikan Islam harus menunjukkan bukti kualitas akademik yang dapat diterima dan dipercaya oleh semua pihak sesuai standar yang telah ditetapkan. Susanto menjelaskan bahwa yaitu indikator mutu lembaga pendidikan dapat dibagi menjadi lima aspek, yaitu: 1) input, 2) proses, 3) output, 4) sumber daya manusia, dan 5) fasilitas. ${ }^{18}$ Input dinyatakan bermutu jika proses kegiatan belajar mengajar terlaksana. Proses dinyatakan bermutu jika suasana belajar aktif, kreatif dan menyenangkan, output dinyatakan bermutu jika hasil belajar siswa baik akademik maupun akademik tinggi.

\section{Metode Penelitian}

Penelitian ini dimaksudkan untuk berupaya mencari dan mengamati insiden dan kasus yang menjadi sorotan pada kajian ini, sehingga dapat dan dideskripsikan apa adanya, persoalan pada kajian ini adalah kasus yang terjadi pada waktu kajian ini dilakukan. Keadaan ini sama dengan konsep kajian deskriptif, di mana peneliti mencoba mendeskripsikan kejadian yang menjadi sorotan serta mendeskripsikan sesua dengan kondisi

${ }^{17}$ Suti. M, Strategi Peningkatan Mutu di Era Otonomi Pendidikan, Jurnal Penelitian Medtek, Vol. 3 No. 2, tahun 2011, h. 2.

${ }^{18}$ Tim SPS UIN Jakarta, Supervisi dan Penjamin Mutu, (Jakarta: Dhifa, 2020), h. 137. 
riil. ${ }^{19}$ Deskripsi yang berupa sketsa dibuat dengan logis, aktual, dan cermat terkait bukti, karakter bersama kaitan antar fenomena yang diteliti melalui kaidah dengan menggunakan data yang didapat, untuk selanjutnya dijabarkan dengan memakai pendekatan kualitatif. Berlandaskan inti dan arah kajian, maka kajian ini merupakan penelitian yang meluas agar mendapatkan fakta yang valid serta terspesifikasi. Kajian ini berniat untuk memperoleh hasil yang mendalam tentang manajemen kualitas jasa layanan pendidikan Islam dengan menggunakan pendekatan fenemenologi. Penelitian fenomenologi yang dibuat oleh peneliti adalah untuk mendalami bagaimana pengalaman responden dengan proses pematangan agar menemukan struktur utama atau sentral di balik pengalaman suatu fenomena.$^{20}$

Selain itu, kajian ini juga diinginkan mampu membentuk satu teori secara induktif, yang nantinya dimanfaatkan untuk menghasilkan temuan substantif sesuai dengan fokus kajian yang diabstraksikan sebagai temuan formal. Artinya informasi yang dikumpulkan bukan berupa angka, melainkan interview, catatan langsung, file pribadi, memorilibia, dan dokumen resmi lainnya. Alasan peneliti menggunakan metodologi kualitatif adalah karena ingin memahami (to understand) secara menyeluruh masalah fenomena, peristiwa atau gejala yang dipelajari untuk mendapatkan pemahaman yang lebih dalam tentang fenomena dan membangun satu teori. ${ }^{21}$ Pendekatan fenemenologi

${ }^{19}$ Sudjarwo, Metodologi Penelitian Sosial, (Bandung: Mandar Maju, 2001), h. 51.

${ }^{20}$ Ginda Rahmita Sari dan Subandi, Akulturasi Psikologis Para Self- Initiated Expatriated. Jurnal Psikologi, 2015, h. 15-16.

${ }^{21}$ Rahardjo, M, Bahan Perkuliahan Metodologi Penelitian Program Doktor Manajemen Pendidikan Islam, (Malang: Pascasarjana UIN Maliki, 2010), h. 35. mendapatkan gejala keabsahan sesuatu itu memancar dari fenomena yang dikaji. ${ }^{22}$

\section{Hasil Penelitian}

Manajemen kualitas jasa pendidikan Islam pada Madrasah Ibtidaiyah Al-Husna Ciledug Kota Tangerang terdiri dari perencanaan, pengorganisasian, pelaksanaan, dan evaluasi yang akan di uraikan sebagai berikut:

1. Perencanaan Manajemen Kualitas Pendidikan di Madrasah Ibtidaiyah AlHusna Ciledug Kota Tangerang.

Dalam membuat manajemen di sebuah lembaga pendidikan Islam di Madrasah Ibtidaiyyah al-husna Ciledug Kota Tangerang,diperlukan suatu perencanaan yang sistematis guna mencapai tujuan yang diharapkan. Begitu pula dengan Madrasah Ibtidaiyyah AlHusna Ciledug yang selalu membuat perencaan program kerja madrasah yang tertuang dalam rencana kerja madrasah. Perencanaan ini membidik pada visi, misi, dan tujuan madrasah. Berdasarkan data wawancara ini dapat ditemukan bahwa kepala madrasah menyusun perencanaan manajemen kualitas pendidikan dalam uraian sebagai berikut:

a. Membuat Rencana Kerja Madrasah

Rencana Kerja Madrasah (RKM) dibuat untuk mengatur selama lima tahun kedepan. Oleh karena itu diperlukan perencanaan yang baik untuk meningkatkan kualitas Madrasah. Rencana Kerja Madrasah di dasarkan pada penilaian diri Madrasah untuk mengukur kinerja dan kemampuan Madrasah Ibtidaiyah. Untuk keberhasilan penyusunan Rencana Kerja Madrasah, semua fungsi yang relevan harus dilibatkan seperti Ketua Yayasan, Komite Madrasah, Kepala Madrasah, dan Dewan

${ }^{22}$ Suharsimi Arikunto, Pendekatan Penelitian, Suatu Pendekatan Praktik, (Jakarta: PT Rineka Cipta, 2013), h. 31. 
Guru. Tokoh masyarakat juga bisa digunakan sebagai sarana pendukung. Tentunya penyusunan rencana kerja madrasah ini akan membawa banyak manfaat yang diantaranya adalah rencana kerja madrasah yang merupakan tolak ukur keberhasilan madrasah dalam mengimplementasikan berbagai jenis program Madrasah. Selain itu, Rencana Kerja Madrasah dapat dijadikan acuan untuk membantu pencapaian tujuan peningkatan mutu pendidikan dalam waktu yang ditentukan. Rencana Kerja Madrasah (RKM) dan Evaluasi Diri Madrasah sangat disarankan untuk Madrasah dapat disusun setiap lima tahun sekali. Diharapkan dengan adanya penjabaran Rencana Kerja Madrasah khusus Madrasah Ibtidaiyah maka tujuan pendidikan dapat tercapai. Dengan cara ini, tujuan Madrasah dapt tercapai karena semua kegiatan untuk lima tahun kedepan telah direncanakan dalam Rencana Kerja Madrasah.

b. Menentukan Kebutuhan Pelanggan Pendidikan Islam

Kepala madrasah mempunyai peranan penting dalam mewujudkan harapan konsumen pendidikan Islam agar terpenuhi kebutuhan. Sebagai pimpinan dan pembuat kebijakan harus memperhatikan ekspetasi pelanggan. Harapan para pendidik dan tenaga kependidikan terhadap kepemimpinan kepala madrasah umumnya bersikap reaktif, positif, optimis, jujur, dan transparan, mematuhi keputusan yang dibuat, pengertian, memahami tujuan pendidikan serta memiliki hubungan yang baik dengan masyarakat. Kepala madrasah sebagai pemegang kendali pendidikan harus trampil dan mampu memberikan kepuasan kepada seluruh komponen pelanggan pendidikan. Kemampuan berkomunikasi dengan baik dan maksimal harus mampu dijalankan oleh kepala madrasah. c. Mengembangkan Program Pendidikan Sesuai Harapan Pelanggan Pendidikan

Dari hasil temuan penelitian tentang manajemen kualitas jasa pendidikan di madrasah ibtidaiyah Al-Husna Ciledug ditemukan usaha pengembangan program pendidikan agar sesuai dengan keinginan dan harapan wali murid sebagai pelanggan pendidikan. Berlandaskan data di tempat penelitian, secara umum ada empat masalah yang utama dan menjadi latar belakang kepala madrasah untuk melakukan pengembangan program pendidikan sesuai keinginan wali murid sebagai pelanggan pendidikan. Adapun yang melatar belakangi pengembangan program pendidikan yaitu pertama masifnya penggunaan media sosial, kedua merosotnya moral generasi muda, ketiga keinginan untuk menjadikan madrasah ibtidaiyah Al-Husna Ciledug menjadi sekolah unggulan di wilayah timur Kota Tangerang, dan keempat ingin menghasilkan generasi yang cerdas sesuai visi, misi, dan tujuan madrasah ibtidaiyah Al-Husna Ciledug. Dalam merumuskan pengembangan program pendidikan agar sesuai dengan harapan wali murid sebagai pelanggan pendidikan, pihak madrasaha ibtidaiyah Al-Husna Ciledug melakukan studi banding ke madrasah atau sekolah yang menjadi role model dalam upaya pengembangan program pendidikan, madrasah atau sekolah yang dijadikan role model dalam pengembangan program pendidikan oleh madrasah ibtidaiyah AlHusna Ciledug adalah madrasah ibtidaiyah negeri 7 Cengkareng Jakarta Barat dan Sekolah Dasar Islam As-Syukriyah Cipondoh Kota Tangerang.

d. Mengembangkan Proses yang Mendukung Pelaksanaan Program Pendidikan

Dari pengembangan program pendidikan yang sudah dituangkan dan ditetapakan dalam KTSP, maka langkah selanjutnya adalah menentukan pendukung agar pelaksanaan program pendidikan untuk 
memenuhi kepuasan dan harapan wali murid sebagai pelanggan pendidikan.

2. Pengorganisasian Manajemen Kualitas Pendidikan di Madrasah Ibtidaiyah AlHusna Ciledug Kota Tangerang.

Pengorganisasian adalah fungsi kedua dalam manajemen dan organisasi. Pengorganisasian adalah proses penyusunan struktur organisasi sesuai dengan tujuan, sumber daya, dan lingkungan, pemilihan dan pengangkatan orang (guru dan personel madrasah lainnya) dan mengalokasikan sarana dan prasarana untuk mendukung tugas orangorang tersebut guna mencapai tujuan madrasah". Dari hasil observasi dokumen dan wawancara mendalam tentang pengorganisasian manajemen kualitas pendidikan di madrasah ibtidaiyah AlHusna Ciledug dapat ditemukan hasil sebagai berikut:

a. Kualitas Pendidik

Kualitas pendidik merupakan tuntutan utama dalam pelayanan pendidikan Islam sehingga kepuasan dan harapan wali murid sebagai pelanggan pendidikan Islam dapat terpenuhi. Standar kualitas pendidik yang diplot oleh madrasah ibtidaiyah AlHusna Ciledug yaitu dengan mengikuti masa observasi selama tiga bulan, memiliki kemampuan mengajar secara profesional, biogrand guru harus dari pendidikan, tepat waktu dalam mengajar, dan berpenampilan rapi

b. Kualitas Tenaga Kependidikan

Kualitas tenaga pendidik merupakan tuntutan pendukung pada tim pendidik di madrasah ibtidaiyah Al-Husna Ciledug. Dalam memberikan pelayanan pendidikan Islam agar kepuasan dan harapan wali murid sebagai pelanggan pendidikan Islam dapat terpenuhi, maka standar kualitas tenaga kependidikan telah diplot oleh madrasah ibtidaiyah Al-Husna Ciledug yaitu harus bersikap ramah dan memberikan informasi yang jelas sesuai tugas pokok dan fungsi

3. Pelaksanaan Manajemen Kualitas Pendidikan Islam di Madrasah Ibtidaiyah Al-Husna Ciledug Kota Tangerang.

Pelaksanaan manajemen kualitas jasa pendidikan Islam adalah tahap utama di madrasah ibtidaiyah Al-Husna Ciledug, hal ini dikarenakan sebagai kulminasi keberhasilan dari sebuah program, pada pelaksanaannya dibutuhkan orang yang andal dalam berkomunikasi dengan publik, sehingga mempunyai pengaruh secara langsung maupun tidak langsung. Untuk menjaga kualitas layanan, diperlukan upaya khusus agar kepuasan dan harapan pelanggan tetap terjaga, maka berdasarkan dari hasil observasi dokumen dan wawancara mendalam tentang pelaksanaan manajemen kualitas jasa pendidikan Islam di madrasah ibtidaiyah Al-Husna Ciledug adalah dengan melakukan relationship marketing, melakukan superior customer service, melakukan pemantauan kepuasan wali murid

1. Evaluasi Manajemen Kualitas Pendidikan di Madrasah Ibtidaiyah AlHusna Ciledug Kota Tangerang.

Evaluasi adalah alat ukur atas keberhasilan atau kegagalan dari suatu program yang telah dilaksanakan, menjadi alat untuk kontrol apakah kegiatan tersebut telah terlaksana atau belum. Kepala madrasah sebagai pimpinan harus melaksanakan program evaluasi pada program pendidikan yang telah dilaksanakan. Pada evaluasi ini, ada kepengawasan dan tindak lanjut. Kegiatan kepengawasan menjadi alat kontrol agar kegiatan sesuai dengan perencanaan, sedangkan program tindak lanjut merupakan proses untuk memberikan ganjaran atau sanksi ketika kegiatan tidak dapat dilaksanakan, selain itu dapat berfungsi sebagai perbaikan ketika menyusun program selanjutnya agar 
menjadi lebih baik. Kegiatan evaluasi yang dilakukan oleh madrasah ibtidaiyah AlHusna Ciledug ini untuk seluruh unit atau bidang di internal madrasah, yang biasanya dilakukan satu kali dalam setiap bulan bertepatan dengan rapat bulanan guru, Selain evaluasi internal, pihak madrasah juga terbuka akan saran dan kritik membangun dari seluruh element pendidikan di madrasah ibtidaiyah AlHusna Ciledug. Masukan dari wali murid yang menjadi pelanggan pendidikan akan berguna untuk meningkatkan kualitas pendidikan di madrasah ibtidaiyah AlHusna Ciledug Kota Tangerang.

\section{E. Penutup}

Berdasarkan Pembahasan tersebut di atas maka dapat di peroleh kesimpulan bahwa perencanaan manajemen kualitas pendidikan di Madrasah Ibtidaiyah AlHusna Ciledug dilakukan dengan a) membuat Rencana Kerja Madrasah (RKM) yang mengacu pada visi, misi, dan tujuan madrasah ibtidaiyah Al-Husna Ciledug, b) menentukan kebutuhan pelanggan pendidikan Islam melalui peningkatan sumber daya madrasah, c) mengembangkan program pendidikan Islam sesuai harapan pelanggan melalui pengembangan program pendidikan Islam yang dituangkan dalam kurikulum Madrasah Ibtidaiyah Al-Husna Ciledug. Pada aspek pengorganisasian dilakukan dengan menerapkan standar kualitas pendidikan dan tenaga kependidikan melalui a) kegiatan sistematis, terstruktur dan terarah, b) menerapkan hubungan yang harmonis dan saling bekerjasama, c) pembagian tugas disesuaikan dengan keahlian. Adapun pada aspek pelaksanaan adalah dengan menempatkan tenaga yang qualified terutama dalam kegiatan kehumasan yang membuat program seperti relationship marketing, superior customer service, dan pemantauan kepuasan wali murid.
Pada aspek Evaluasi adalah dengan melakukan evaluasi internal yang dilakukan pada rapat bulanan serta evaluasi eksternal berupa masukan dari wali murid yang menjadi pelanggan pendidikan akan berguna untuk meningkatkan kualitas pendidikan.

\section{DAFTAR PUSTAKA}

Arikunto, S. (2013). Pendekatan Penelitian (Suatu Pendekatan Praktik). Jakarta: Rineka ipta.

Bashori. (2017). Strategi Kompetitif Lembaga Pendidikan. Journal Pendidikan Islam.

Eferi, A. (2014). Dinamika Persaingan Antar Lembaga Pendidikan. Journal of Emperical Islamic Education.

Erlita, N. (2018). The Website The Website Management of www ppid.dpr.go.id in public information services 2014. American Journal of Humanites and Social Science Reseach.

Ginda Rahmita Sari dan Subandi. (2015). Akulturasi Psikologis Para SelfInitiated Expatriated. Jurnal Psikologi.

Iman, M. S. (2004). Pendidikan Partisipatif : Menimbang Konsep Fitrah dan Progresivisme John Dewy. Yogyakarta: Safiria Insani Press \& MSI UII.

Jakarta, T. S. (2020). Supervisi dan Penjamin Mutu. Jakarta: Dhifa.

kartika, Q. (2017). Dinamika Lembaga Pendidikan Mmepertahankan Eksistensi Pada era kompetitif. Journal of Islamic Educational Management.

Kritiner, R. (1989). Management. Boston: Houhgton Miffin Commpany. 
M, S. (2011). Strategi Peningkatan Mutu di Era Otonomi Pendidikan. Jurnal Penelitian Medtek.

Manulang, M. (2005). Dasar-Dasar Manajemen. Yogyakarta: Gajah Mada Univ. Press.

Maryadi. (2017). Manajemen Pemasaran Perguruan Tinggi Sebagai Salah Satu Kunci Keberhasilan Dalam Menghadapi Persaingan. Jurnal Karimah.

Muslich. (2004). Etika Bisnis Islami: Landasan Filososfis, Normatif, dan Substansi Implementatif. Yogyakarta: Ekonosia.

Nafis, A. S. (2012). Manajemen Pendidikan Islam. Yogyakarta: Laksbang Pressindo.

Rahardjo, M. (2010). Bahan Perkuliahan Metodologi Penelitian Program Doktor Manajemen Pendidikan Islam. Malang: Pascasarjana UIN Maliki.

Sallis, E. (2016). Total Quality in Education. London: Kogan Page Limited.

Sharma, A. K. (2000). Principlies Of Busines Management. New Delhi: Atlantics Publisher anad Distributors.

Soejono. (1997). Aliran Baru dalam Pendidikan. Bandung: CV. Ilmu.

Stoner, J. F. (2005). Management. New Jersey: Prentice Hall.
Sudjana, H.D (2004). Manajemen Program Pendidikan. Bandung: Falah Production.

Sudjarwo. ( 2001). Metodologi Penelitian Sosial. Bandung: Mandar Maju.

Sulistyorini. (2005). Manajemen Pendidikan Islam. Tulungagung: STAIN Tulungagung.

Tafsir, A. (2012). Filsafat Pendidikan Islam. Bandung: PT. Remaja Rosdakarya.

Weihrich, H. K. (2008). Essential Of Management an International Perspective. New Delhi: Tata McGraww-Hill Publishing Company. 